\title{
O reacionarismo da burguesia brasileira: Sinal de decadência ideológica?
}

\author{
Rodrigo Bischoff Belli ${ }^{1}$
}

\section{Resumo}

Este artigo pretende apresentar uma hipótese sobre o caráter reacionário da burguesia brasileira. Admite-se, a princípio, que, se comparada com outras manifestações da classe dominante no modo de produção capitalista, a burguesia desenvolvida nessa antiga colônia portuguesa apresenta características bastante peculiares. De modo que sua expressão se afasta do movimento comum de constituição da classe dominante no capitalismo sem, no entanto, deixar de compor a unidade dessa dinamicidade.

Palavras-chave: burguesia brasileira; decadência ideológica; capitalismo.

\section{The reactionarism of brazilian bourgeoisie: Sign of ideological decadence?}

\begin{abstract}
This article intends to present a hypothesis about the reactionary character of Brazilian bourgeoisie. It is admitted, a beginning, if compared with other manifestations of dominant class in capitalist mode of production, which the bourgeoisie developed in that old portuguese colony presents quite peculiar characteristics. So that its expression stands back from common movement of dominant class constitution without, meanwhile, leaving compose the dinamic of that unit.
\end{abstract}

Keywords: Brazilian bourgeoisie; ideological decadence; capitalism.

\section{Introdução}

O início do século XX foi o momento de consolidação do capitalismo no Brasil. De meados dos anos 1920, passando pelo levante de 1930, até chegar aos anos da ditadura militar, cristalizam-se relações econômicas comuns àquilo que se denomina como modo de produção capitalista. Este, nunca é demais esclarecer, se fundamenta numa configuração entre forças produtivas e relações de produção em que vigoram a produção individualizada dos bens necessários para a sobrevivência da humanidade através da constituição de produtores completamente livres de quaisquer obrigações hierárquicas que

\footnotetext{
${ }^{1}$ Doutorando do Programa de pós-graduação em Ciências Sociais da Faculdade de Filosofia e Ciências da Universidade Estadual Julio de Mesquita Filho (UNESP), bolsista da CAPES.
} 
não estejam baseadas em contratos legais. ${ }^{i}$ Uma das principais características do modo de pensar e agir mediado por relações capitalistas é a organização da atividade produtiva centrada no trabalho assalariado, algo extremamente propício num ambiente urbano e industrializado. O período anunciado no início deste artigo representa a consolidação destas características no Brasil. No entanto, como aconteceu em cada localidade do mundo, a inserção de um determinado território e de uma determinada população no mercado mundial ocorre de maneira bastante diferente umas das outras.

Essa variedade na configuração do capitalismo se expressa na maneira como se dá a dominação de classe. Se nos países que vivenciaram um período de transição realmente revolucionário a burguesia tratou de assumir a frente do processo, alterando as instituições políticas e colocando seus interesses econômicos acima de tudo, já nos países que foram forjados enquanto colônias europeias o processo capitalista determinou o surgimento de uma forma de ser da classe dominante nacional marcada pela subserviência estrangeira e pelo comodismo das estruturas de dominação. O exercício de seu poder político é marcado pela manutenção de formas arcaicas e de atividades econômicas que não enfrentavam competitivamente o exercício do controle do mercado mundial pelas burguesias dos países capitalistas centrais, e também por uma forma miserável de proceder aos conflitos existentes contra as classes dominadas, bem como aos seus rivais burgueses de outros países. Diferente da gênese capitalista em território europeu, a cristalização do modo de produção capitalista no restante do mundo, especialmente do mundo colonizado, combinou um momento de grande expansão de economias capitalistas já existentes no exterior com uma estrutura social de mercantilização simples e superexploração do trabalho, por regimes de trabalho escravagistas, ou semelhantes a isso. ${ }^{\text {ii }}$ A burguesia brasileira não se esforça em transformar consideravelmente as instituições políticas, tal como suas versões similares originalmente fizeram no centro da dinâmica capitalista. O processo de formação da burguesia que hegemoniza as relações de classe no período de cristalização do capitalismo no Brasil é exemplar dessa condição submissa e reacionária, que representaria, do ponto de vista geral da história da cultura humana, um aspecto decadente. 


\section{Os turbulentos anos de consolidação do capitalismo no Brasil}

Aos meados do século XIX, o que ocorre na luta de classes no Brasil é o surgimento de uma nova fração da classe dominante, que dinamiza um novo arranjo de relações sociais e políticas a partir das formas econômicas já existentes. Se até o período em questão predominava uma elite fundamentada no grande latifúndio canavieiro, beneficiada pela tutela monopolística de Portugal e da Holanda, a partir da ascensão da economia cafeeira autonomizam-se uma série de frentes necessárias para a produção e distribuição do café no mercado mundial. A elite cafeeira precisava ser mais incisiva em suas ações para se estabelecer dentro das relações mundiais de mercado, promovendo a modernização logística e a intervenção na política econômica nacional, algo que não combinava com as relações remanescentes do período colonial materializadas nas terras de engenho (FAUSTO, 1975, p. $88)$.

Mesmo entrando em conflito com a fração de classe dominante já existente, a elite vinculada à cultura cafeeira não tem outro interesse senão manter o Brasil como país satélite dos grandes centros capitalistas da época. Se nos tempos da cana-de-açúcar essa característica de dependência derivava diretamente dum regime produtivo extrativista, desta o café viabilizava uma inserção econômica distinta, que dava margem de ação ao mercado financeiro. Por ser produtor monopólico da cultura no mundo inteiro, a burguesia nacional tomava vantagem dessa condição para controlar a produção e a circulação das sacas de café, interferindo diretamente nos interesses dos atravessadores e na maneira como se relacionava com o mercado, em suas diferentes facetas. Se as exportações giravam principalmente entre Estados Unidos e Europa, tendo na Alemanha uma grande competidora, as importações e os empréstimos circundavam as relações com a Inglaterra, fazendo resistir a cadeia de dominação britânica existente desde o período imperial (FAUSTO, 1975, p. 88).

Esta relação nova que se estabelece abre condições para que surja uma burguesia nacional brasileira. Esta classe social estabelece seu controle do poder político ao longo dos anos de constituição da política do "café com leite". iii A Constituição de 1891 e a política dos governadores aplicada pelo 
governo do presidente Campos Sales expressam o controle da elite cafeeira, em grande medida paulista, nos caminhos do desenvolvimento nacional. ${ }^{\text {iv }}$

Mas, se o Brasil se constituía como um satélite das economias nacionais europeias e estadunidense, dentro do seu território não havia uma plena homogeneidade nos interesses. Num território consideravelmente grande como o brasileiro, também se consolidava um fracionamento de interesses das diversas elites existentes, cada uma se concentrando numa determinada região, cada uma num determinado tipo de cultura. Deste modo, algumas regiões do país se apresentavam à dianteira das atividades econômicas, enquanto que outras circundavam sua esfera de interesses, tentando tirar o máximo proveito da relação de dependência estabelecida. ${ }^{\mathrm{V}}$

Assim, diante de tantos embates entre as diferentes frações da classe dominante, o sistema originalmente desenvolvido pela elite cafeeira apresenta fissuras. Estas se manifestam na insatisfação das chamadas "classes médias" com a falta de um projeto realmente nacional por parte do núcleo político dominante. Mais do que criticar a estrutura econômica nacional, o que se questionava era a maneira como se organizava a política: de como o interesse nacional estava balizado nos interesses de um grupo restrito, e que esses interesses correspondiam, na verdade, mais aos interesses externos encarnados na figura da financeirização mundial - que esticava seus tentáculos na medida em que avançava, junto com o mercado mundial, aos últimos rincões do planeta - e no aumento gradativo da exploração e do controle da produção na mão de pequenos grupos.

Nos primeiros anos do século XX o Brasil vivenciou um período bastante turbulento. A classe média, concentrada pelo funcionalismo público das grandes cidades que se desenvolviam graças ao surto industrial provocado pelo ouro verde, se via numa contradição cada vez maior, pois que seus interesses destoavam das grandes oligarquias. Isso se refletia na insatisfação com a política do "café com leite", que monopolizava o poder político nas elites rurais. Dentro das Forças Armadas, essa insatisfação também ocorria. Tanto que o tenentismo, um movimento que envolveu numa série de rebeliões de jovens oficiais de baixa e média patente do Exército Brasileiro, torna-se sua mais expressiva manifestação (SANTA ROSA, 1976, p. 43).

O tenentismo surgiu nos quartéis espalhados em todo território nacional a partir da década de 1920. Os oficiais revoltosos se opunham às condições políticas impostas pelas elites, encarnadas 
principalmente na burguesia cafeeira. A contradição existente entre o modo de vida burguês refletido nas políticas econômicas, bem como nas instituições públicas, e o modo de vida pequeno burguês dos funcionários públicos e do oficialato militar era algo que se tornava cada vez mais visível, e precisava ser superado por uma resposta que trouxesse algo novo. Ao contrário da burguesia nacional que mantinha praticamente intactas as estruturas de poder existentes desde o período colonial, o movimento tenentista, na necessidade de buscar o novo, dá uma resposta pretensamente radical: ao invés de mudar para manter tudo como estava, seria preciso alterar a correlação de forças a seu favor, para que fosse possível empregar a sua visão de mundo (SANTA ROSA, 1976, p. 43).

As expressões de classes médias brasileiras, devido à dependência estrutural das oligarquias mantida por relações vigentes desde o período colonial, são incapazes de se organizar por conta própria para expressar autonomamente seus interesses e contestar o poder oligárquico estabelecido. As Forças Armadas, representadas pelos tenentes, são uma alternativa a isso, por compartilharem pontos de toque em suas formulações ideológicas. Estas assumem, assim, o papel de porta-voz das aspirações das camadas médias urbanas.

A crise da República Velha ao longo da década de 1920 e a crise de superprodução do café em 1929 tumultuaram o início dos anos 30. Com a crise, as importações de café diminuíram drasticamente, aumentando os estoques internos desde há muito saturados, diminuindo, consequentemente, os preços no mercado mundial. Para evitar uma desvalorização ainda maior, o governo brasileiro chegou a comprometer toneladas de café, diminuindo sua oferta e estabilizando, mesmo que momentaneamente, seu preço. A necessidade de se alterar a atividade predominante no Brasil acirrou ainda mais a relação entre a burguesia cafeeira dominante e novas frações da elite nacional, de tendências industrialistas. A frente liderada por Getúlio Vargas assume o poder, mas se mantém sempre sob a sombra de um possível golpe da burguesia cafeeira. Não apenas o de Getúlio, mas também os governos de Juscelino Kubistchek e João Goulart foram marcados por esse cenário (BANDEIRA, M., 1983, pp. 64-74).

Por mais que os governos de Vargas, JK e Jango não tivessem uma perspectiva revolucionária pautando seus respectivos programas, eles foram marcados por uma tentativa de superação do predomínio político das antigas oligarquias. Isto demandava uma aproximação com os setores da população mais ligados à classe trabalhadora. O caráter tendencialmente popular desses novos 
governos, ainda mais contrapostos à política do período anterior, significava, mesmo que de maneira limitada, uma transformação nas condições gerais de produção e manutenção da vida no Brasil. Sentindo-se ameaçada e em defesa de seus interesses, a burguesia expressa a necessidade em reagir:

Ora, as elites brasileiras não estavam preparadas para as duas transformações concomitantes. Acomodaram-se de modo mais ou menos rápido à primeira diferenciação, que brotava no ápice da sociedade e podia ser tolerada como uma divergência intra muros e que, no fundo, nascia de uma pressão natural para ajustar a dominação burguesa a seus novos quadros reais. No entanto, viram os efeitos da segunda diferenciação como um desafio insuportável, como se ela contivesse uma demonstração de lesa-majestade: as reservas de opressão e de repressão de uma sociedade de classes em formação foram mobilizadas para solapá-la e para impedir que as massas populares conquistassem, de fato, um espaço político próprio, "dentro da ordem”. Essa reação não foi imediata; ela teve larga duração, indo do mandonismo, do paternalismo e do ritualismo eleitoral à manipulação dos movimentos políticos populares, pelos demagogos conservadores ou oportunistas e pelo condicionamento estatal do sindicalismo (FERNANDES, 1975, p. 208).

Esta disputa de pequenos e restritos interesses que pretendem ser universais, mas que não são capazes de sê-los de fato provoca a necessidade de uma resolução pelas partes envolvidas. A resposta dada e que se mostrou eficiente foi a de mudar certos fatores para que nada, essencialmente, pudesse ser mudado. O golpe efetuado em 1964 para ser paradigmático neste sentido. Mas é importante lembrar que esse tipo de resposta foi comum desde o início da constituição do Brasil.

\section{O processo de conformação do capitalismo global}

A formação diferenciada do Brasil, enquanto uma colônia europeia que surge no período de expansão do mercado mundial através das grandes navegações realizadas a partir do século XV, determina consideravelmente a constituição da burguesia nacional. Em geral, como lembra Prado Jr., a história do descobrimento costuma ser apresentada por si mesma, como se uma série de acontecimentos anteriores que motivariam os sujeitos históricos e delimitariam suas ações ao longo do tempo não tivessem acontecido, ou, então, possuíssem uma importância menor em face do devir inaugurado com o início da colonização das terras do outro lado do Atlântico. Ora, o mercado mundial, mesmo bastante restrito a Europa, partes da Ásia e da África, já começara a se constituir, promovendo mudanças significativas na conjuntura geopolítica da época. Os países localizados no centro do continente 
europeu, até então as principais nações mercantis da época, cedem espaço para os países litorâneos. Estes passam, pelo controle dos portos, a ditar o ritmo de circulação das mercadorias, trazendo consigo, consequentemente, a necessidade de pensar novas maneiras de exercer e aumentar, intensiva e extensivamente, esse controle (PRADO JR. C., 2000, pp. 9-10).

Neste sentido, é importante avaliar a empresa colonizadora nas Américas como uma atividade orientada por um interesse especifico: a expansão do mercado mundial em benefício às grandes potências europeias.

Tudo isto lança muita luz sobre o espírito com que os povos da Europa abordam a América. A ideia de povoar não ocorre inicialmente a nenhum. É o comércio que os interessa, e daí o relativo desprezo por este território primitivo e vazio que é a América; e inversamente, o prestígio do Oriente, onde não faltava objeto para atividades mercantis. A ideia de ocupar, não como fizera até então em terras estranhas, apenas como agentes comerciais, funcionários e militares para a defesa, organizados em simples feitorias destinadas a mercadejar com os nativos e servir de articulação entre as rotas marítimas e os territórios ocupados; mas ocupar com povoamento efetivo, isto só surgiu como contingência, necessidade imposta por circunstâncias novas e imprevistas (PRADO JR. C., 2000, pp. 9-10).

Apenas em um segundo momento, em que as primeiras levas de colonizadores encontram dificuldades bastante grandes de manutenção de sua vida nessas novas terras, e na chegada de uma série de novos agrupamentos vindos com a principal motivação de realizarem uma nova rotina, muito distinta daquela vivenciada na Europa do período, marcada por guerras, doenças, pobreza e perseguições (PRADO JR. C., 2000, pp. 13-14). Mas é importante ressaltar que essa nova vida de fato era imaginada como nova. Se se considerarmos a vida humana como manifestação cultural, e considerarmos a cultura como expressão humana mais legítima que se origina e transborda da atividade do trabalho, os colonos europeus que chegavam com esse propósito carregavam consigo as marcas do campesino ou do homem livre, submetidos aos interesses dos senhores e dos mestres de oficio. Uma nova vida para eles só poderia brotar numa configuração distinta da divisão do trabalho, de modo que eles assumissem a atividade de controle da produção.

Mas os conflitos de classe não cessam por boa vontade. Tanto colonos quanto escravos trabalhariam nas novas terras de acordo com os interesses das elites metropolitanas, e este era, em grande medida, transformar as colônias em seu entreposto comercial, garantindo o abastecimento de 
produtos primários nos países centrais e também garantindo a vasão de produtos manufaturados para as colônias.

Deste modo, as colônias americanas tinham uma característica bastante peculiar:

[...] será a empresa do colono branco, que reúne à natureza pródiga em recursos aproveitáveis para a produção de gêneros de grande valor comercial, o trabalho recrutado entre raças inferiores que domina: indígenas ou negros africanos importados. Há um ajustamento entre os tradicionais objetivos mercantis que assinalam o início da expansão ultramarina da Europa, e que são conservados, e as novas condições em que se realizará a empresa (PRADO JR. C., 2000, p. 19).

Este quadro de subordinação das elites criadas em território colonizado se mantém por um longo tempo, e passa a ser fortemente ameaçado na transição do século XVIII ao XIX, com a penetração de certas mudanças nos conflitos de classe motivadas pela expansão global do mercado, agora já nos marcos do modo de produção capitalista. O processo de expansão do mercado mundial encontra seu momento-chave de cristalização justamente no período das chamadas revoluções burguesas, em que a burguesia, classe subordinada à aristocracia no modo de produção feudal, começa a efetivar uma série de transformações variadas a fim de implantar a indústria e o trabalho assalariado como atividade econômica e regime de produção preponderantes. Segundo Fernandes:

$\mathrm{Na}$ acepção em que tomamos o conceito, Revolução Burguesa denota um conjunto de transformações econômicas, tecnológicas, sociais, psicoculturais e políticas que só se realizam quando o desenvolvimento capitalista atinge o clímax de sua evolução industrial. Há, porém, um ponto de partida e um ponto de chegada, e é extremamente difícil localizar-se o momento em que essa revolução alcança um patamar histórico irreversível, de plena maturidade e, ao mesmo tempo, de consolidação do poder burguês e da dominação burguesa (FERNANDES, 1975, 203).

Mas no Brasil, desde o período da colonização até os umbrais do império, não há constituída uma burguesia nos moldes clássicos apontados por Fernandes. As relações de classe estabeleciam uma relação entre dominantes e dominados baseado em formas pré-capitalistas, mas subordinadas à dinâmica do mercado mundial. Havia, portanto, oligarquias que efetivavam um regime de trabalho não próprio ao capitalismo, mas ainda assim integrado a esse sistema. Uma expressão da complexidade da formação desse modo de produção a nível mundial que encontra um correspondente teórico na categoria de acumulação primitiva. ${ }^{\text {vi }}$ 
$\mathrm{Na}$ entrada do século $\mathrm{XX}$, o poder oligárquico estabelecido anteriormente pela relação de dependência da colônia brasileira para com a metrópole portuguesa começou a ser abalado. Mas ao contrário do que esse termo supõe, tal estremecimento das estruturas de poder no Brasil não estavam para ser alteradas em sua substância mais importante. No Brasil, a revolução burguesa não tomou os rumos comuns aos países capitalistas centrais, tal como apontado pela caracterização citada a pouco de Fernandes. O que ocorre é outro tipo de fenômeno, marcado pela recomposição das estruturas de classe e de poder, afirmando uma nova maneira de a burguesia nacional exercer seu poder dentro dos marcos do capitalismo mundial.

Como lembra Fernandes:

É dessa debilidade que iria nascer o poder da burguesia. Porque ela impôs, desde o início, que fosse no terreno político que se estabelecesse o pacto tácito (por vezes formalizado e explícito) de dominação de classe. Ao contrário de outras burguesias, que forjaram instituições próprias de poder especificamente social e só usaram o Estado para arranjos mais complicados e específicos, a nossa burguesia converge para o Estado e faz sua unificação no plano político, antes de converter a dominação socioeconômica no que Weber entendia como "poder político indireto" (FERNANDES, 1975, 204).

A oligarquia se transforma, não cedendo espaço ao novo. Essa condição caracteriza a burguesia nacional como oportunista e conservadora. Embora seja de fato uma burguesia, uma classe social que precisa assumir a frente dos processos de produção econômica da formação social da qual exerce seu poder de dominação, ela não consegue realizar isso fora de seu âmbito de atuação, ou seja, no meio empresarial. Toda vez que tentou sair desse espaço, não logrou sucesso, a não ser com o auxílio de outros agrupamentos sociais, que cumpriam esta função de classe para ela. O golpe militar de 1964 representaria, para Fernandes, esse movimento. O grupo dos militares realiza, com o golpe, a ativação de instrumentos autocráticos de exercício do poder que convém diretamente para essa burguesia conservadora.

A convergência de interesses burgueses internos e externos fazia da dominação burguesa uma fonte de estabilidade econômica e política, sendo esta vista como um componente essencial para o tipo de crescimento econômico, que ambos pretendiam, e para o estilo de vida política posto em prática pelas elites (e que servia de suporte ao padrão vigente de estabilidade econômica e política). Portanto, a dominação burguesa se associava a procedimentos autocráticos, herdados do passado ou improvisados no presente, e era quase neutra para a formação e a difusão de procedimentos democráticos alternativos, que deveriam ser instituídos 
(na verdade, eles tinham existência legal ou formal, mas eram socialmente inoperantes (FERNANDES, 1975, 207).

E ela o realiza tão formidavelmente, que nem mesmo a burguesia é capaz de parar por conta própria sua irresistível tendência em adotar medidas extremas na luta de classes no Brasil.

Portanto, esse poder só poderia ser invocado, nas condições existentes, ou "a partir de cima e de dentro" (na forma de conflitos de facção, no seio das classes dominantes, considerando-se os setores intermediários como parte delas, o que de fato eram, em termos de relações de parentesco ou de lealdade e pelo consenso social), ou pela via da "oposição consentida" (que só poderia envolver conflitos ou dissensões controláveis "a partir de cima" e de interesse direto ou indireto para as "forças da ordem"). Essas duas linhas mesclavam-se, em várias direções, e tornavam, ao mesmo tempo, débeis e corruptas (ou corruptíveis) as "forças de oposição democrática", que assim eclodiam dentro da ordem e sob seu controle. Isso não só explica a feição tomada pelas rebeliões militares na década de 20, pela revolução da Aliança Liberal ou pela Revolução Constitucionalista, em 30 e 32, e outros movimentos posteriores. Também explica a exacerbada insegurança demonstrada pela burguesia diante dos movimentos demagógico-populistas ou da pressão sindical (todos mais ou menos "controlados a partir de cima"), e sua extrema intolerância diante de manifestações potencial ou efetivamente autônomas do movimento operário. Ao que parece, onde a dominação burguesa não se revela capaz de mobilizar e aplicar semelhante reserva de poder, ela corre o risco de ser facilmente deslocada por grupos que invadem o referido espaço político: não importa se em nome de uma "revolução dentro da ordem" ou da "simples consolidação do regime". Isso faz com que a intolerância tenha raiz e sentido políticos; e que a democracia burguesa, nessa situação, seja de fato uma "democracia restrita", aberta e funcional só para os que têm acesso à dominação burguesa (FERNANDES, 1975, p. 212).

\section{A burguesia nos primórdios do capitalismo}

O comportamento da burguesia diante desse cenário se distingue consideravelmente daquele adotado originalmente pelas burguesias europeias. No entanto, ao longo do processo de cristalização desse modo de produção no velho mundo, a nova classe dominante se viu envolta por um conflito maior do que imaginava. Se não bastasse ter de se confrontar com a decadência da aristocracia, ela agora deveria tomar maiores cuidados com os trabalhadores assalariados, uma classe social que surgiu concomitantemente ao exercício de dominação burguesa e que destarte já se opunha a ela. Neste momento, a burguesia, que até então tinha um ímpeto revolucionário - por sua condição de vida ser possível de efetivar apenas com a derrubada completa, pela raiz, da ordem feudal aristocrática - tem de adotar, para manter sua recém-conquistada condição, uma postura conservadora. 
Nas formações sociais europeias, especialmente naquelas que compunham localidades centrais no mercado mundial de trocas que se agigantava a partir do período da colonização do território americano, a burguesia apresentava um caráter prático e ideológico revolucionário em seus primórdios. No combate total à ordem feudal, na quebra do pensamento escolástico, na derrubada do poder aristocrático e na instituição da indústria como forma de produção econômica capaz de produzir um tipo de excedente econômico mais vantajoso do que aquele propiciado pela atividade agrícola, a burguesia surgia como classe social impulsionadora de transformações radicais nas relações humanas.

De uma formação social marcada por uma atividade econômica baseada na terra - para ser mais preciso, pela propriedade da terra, mais do que pelo trabalho realizado sobre ela - para outra em que predomina o trabalho assalariado progressivamente industrializado, existem transformações culturais consideráveis. A própria condição da propriedade da terra ser fator importantíssimo nas relações sociais denuncia a diferença. A estrutura de classes das sociedades agrárias no modo de produção feudal europeu se fundava numa hierarquia baseada em privilégios ligados à propriedade, algo que garantia às classes dominantes uma ativa participação política, mas que na manutenção econômica da vida implicava, gradativamente, uma série de reveses. Como o dinheiro advindo da propriedade não é exatamente um lucro gerado da criação de um novo valor, mas sim uma renda retirada de uma determinada atividade, como o caso do arrendamento, pode ocorrer, assim como ocorreu, de fato, uma discrepância muito grande entre os preços das mercadorias e os ganhos obtidos. O modo de vida da aristocracia minava sua própria condição econômica, enfraquecendo-a também do ponto de vista político (HOBSBAWM, 2005, pp. 35-36).

A transformação dessa condição deveria, portanto, ter como fundamento o afastamento das relações baseadas na propriedade da terra. Não que devessem ser eliminadas por completo, mas sim tornadas menos importantes a cada passo da história. Isso é importante ser ressaltado porque a transformação que resultará na transição do feudalismo para o capitalismo tem por base ainda a questão da terra. A maior das revoluções não acontece se não mantiver certos fatores necessários para a manutenção da nova formação social que se apresenta. No caso do surgimento do capitalismo, a terra ainda era uma das principais forças produtivas. Na Inglaterra, principal caso desse processo, o surgimento do capitalismo se dá por um processo de mercantilização do campo que leva ao trabalho 
assalariado dos camponeses em terras não mais suas e cada vez mais concentradas na mão de empresários. Estes, oriundos do comércio, não possuem os privilégios políticos aristocráticos, mas sua força econômica lhes garante uma gradativa e decisiva entrada na máquina estatal, e no seu alçamento à classe dominante, difusora ferrenha de uma nova cultura (HOBSBAWM, 2005, pp. 35-36).

Isso significava que a complexidade da vida humana tomava novos rumos. A agricultura cedia espaço cada vez mais à atividade industrial, tendencialmente mais valiosa, e com ela a organização do espaço e do cotidiano. As formas de decisão política e a contagem do tempo baseadas nos tempos de cada cultura agrícola são superadas por novas instituições fundadas na rotina de trabalho imposta pela organização do espaço urbano, medido com rigor quantitativo pelos ponteiros do relógio. A ciência, esfera humana em que essa quantificação da realidade surge com maior rigor, começa a se desenvolver duma maneira exponencial. A derrocada da aristocracia e da ideologia escolástica que fundamentava culturalmente seu domínio de classe ajudou a abrir os caminhos de uma prática e de uma visão de mundo dispostas à inovação. $\mathrm{O}$ avanço do conhecimento do mundo com a quebra constante de paradigmas teóricos trouxe à cena uma nova visão de mundo, o iluminismo, própria de um novo tipo de pessoa, voltada para atividades exclusivamente intelectuais num ambiente urbano e, também, debitária da tradição clássica (HOBSBAWM, 2005, pp. 41-42).

Não foi à toa que o iluminismo, por mais que expressasse uma tendência universal de desenvolvimento cultural, serviu também a interesses de classe bastante particulares, como os da burguesia. O progresso científico coincidia com a derrubada da cultura aristocrática, feito necessário para ao avanço da nova cultura capitalista, marcada pela necessidade do reconhecimento do indivíduo enquanto produtor e consumidor capaz de expandir os limites do mercado a nível mundial. Era o fim dos privilégios baseados na propriedade e o início da valorização da empresa individual como fonte de reconhecimento social. A burguesia, assim, precisa revolucionar valores, modifica-los pela raiz, para poder exercer seu poder enquanto classe dominante e manter-se à frente na nova hierarquia estabelecida pela divisão do trabalho no mercado mundial, ao contrário da ultrapassada aristocracia, cuja forma de manutenção no poder e caracterizou, em grande medida, em adotar uma postura reacionária, negadora dos novos valores, indo contra a corrente das tendências abertas pela atividade econômica em expansão. 
No entanto, por volta de 1848, a burguesia dos países capitalistas centrais parece sofrer uma inflexão. O seu modo de vida, estabelecido num processo de lutas revolucionárias, se contrapõe aos interesses da classe trabalhadora, tornando a relação entre as duas um verdadeiro antagonismo. Nessa situação, as burguesias lançam mão de seus ideais e práticas revolucionárias e passam a adotar uma postura conservadora que salvaguarda seus interesses, ou seja, que protege o conjunto das relações sociais que lhes beneficiam em detrimento dos subordinados assalariados.

Tal mudança de postura política possui consequências culturais importantes: o pensamento científico aprimorado no embate com o pensamento escolástico se degenera num empirismo que o torna gradativamente tacanho; a necessidade observada de extensão da participação política é refreada constantemente; a satisfação dos interesses do mercado tornam-se mais importantes do que os interesses dos seres humanos. Trata-se, aqui, de um fenômeno de decadência ideológica.

\section{A burguesia em decadência e o desenvolvimento do capitalismo}

A categoria de decadência ideológica ${ }^{\text {vii }}$ remete a um exercício constante de respostas idealizadas para o exercício de uma determinada prática; uma prática que pudesse contornar uma situação bastante complicada no momento: a de que as armas da crítica criadas pela burguesia para a superação do modo de produção feudal, e para o seu consequente estabelecimento como classe dominante no capitalismo, começavam a se voltar contra ela através dos movimentos populares, que já ganhavam contornos classistas. Essa decadência da burguesia, que teria alcançado os mais variados níveis das relações sociais - como a política, a ciência, a filosofia, as artes, o cotidiano, etc. -, correspondia, então, a tentativa de forjar respostas que superassem essa situação incômoda. Neste sentido, não há nada de negativo: superar problemas faz parte, e se constitui positivamente na reprodução da vida humana. No entanto, ao invés de saltar os umbrais estabelecidos à época para se alcançar novas alturas e tratar de estabelecer uma nova plataforma de partida, a burguesia, em geral, tratou de dar respostas que colocavam, em uma nova forma, formulações bastante antigas, que embora fossem logicamente coerentes, representavam uma espécie de reconciliação com a filosofia derrotada durante o seu período revolucionário. E o faz por querer evitar a todo o custo trilhar os caminhos abertos pelo pensamento 
comunista, que apesar de herdeiro do iluminismo, propunha uma agenda, um projeto de mundo bastante distinto daquele ambicionado pelos primeiros filósofos burgueses. Ou seja, em nome do conservadorismo, a burguesia passa a adotar um caráter reacionário.

Como se daria isso, nas palavras de Lukács:

Essa liquidação de todas as tentativas anteriormente realizadas pelos mais notáveis ideólogos burgueses no sentido de compreender as verdadeiras forças motrizes da sociedade, sem temor das contradições que pudessem ser esclarecidas; essa fuga numa pseudo-história construída a seu bel-prazer, interpretada superficialmente, deformada em sentido subjetivista e místico, é a tendência geral da decadência ideológica. ${ }^{\text {viii }}$

O pensamento burguês em sua fase decadente não supera as contradições impostas pela realidade. Existe uma teoria harmônica sobre uma realidade que não é harmônica, e o pior, há a tendência por parte dessa corrente filosófica em fugir das contradições, exaltando a calmaria teórica das suas próprias formulações. Trata-se, portanto, de uma filosofia apologética, que elogia a si mesma no plano lógico para tergiversar sobre os problemas postos pela realidade e cuja solução estaria na superação das condições que fazem da burguesia o que ela é.

Um exemplo dessa situação é a transformação sofrida pela economia política, principal expressão da ideologia burguesa no período de consolidação do capitalismo na Europa. Se os seus teóricos clássicos, Adam Smith e David Ricardo, por mais interesses que pudessem ter nos estudos sobre economia, conseguiram elaborar um tipo de conhecimento que, mesmo contradizendo suas vontades, encontrava forte correspondência na realidade. Ela era, de fato, uma expressão científica daquele momento. No entanto, as contradições surgidas dessa empreitada não foram resolvidas por seus formuladores, tornando-se um problema a ser resolvido pelas gerações futuras. Foram estas que, ao contrário dos clássicos, forjaram respostas que favoreciam muito mais seus interesses de classe do que propriamente condiziam com a realidade. E isto tudo como uma forma de defesa dos interesses recém-cristalizados. Como explica Lukács, no caso de Stuart Mill, um dos representantes dessa nova postura da economia política:

Com isto [negação dos contrastes existentes a favor de uma suposta harmonia], Mill abre a porta à mais trivial apologética da economia vulgar. De suas investigações, que ainda devem ser parcialmente levadas a sério, um rápido atalho leva à exaltação vazia da 'harmonia' do capitalismo, aos múltiplos Say, Bastiat, Roccher. A economia se limita, cada vez mais, a uma mera reprodução dos fenômenos superficiais. O processo espontâneo da decadência científica opera em estreito contato com a apologia consciente e venal da economia capitalista. ${ }^{\text {ix }}$ 
Os problemas postos pela filosofia da decadência ideológica não se diferem daqueles encontrados no período anterior. A diferença reside na maneira como estes problemas serão tratados, tanto no que diz respeito ao método quanto na motivação do próprio intelectual.

O fenômeno da decadência ideológica retoma a ideia de que a reprodução de determinada formação social, em sua maneira de produzir incessantemente as condições necessárias à vida das pessoas que a compõem, não é composta unilateralmente pela política ou pela economia. A ideologia pode ser caracterizada como a resposta dada pelas próprias pessoas em suas vivências aos problemas que se apresentam. ${ }^{\mathrm{x}}$ Perscrutando a história da humanidade em suas formas de organização mais primitivas, e, portanto, mais simples, a divisão do trabalho já apresenta uma nova forma do gênero humano encarar os desafios que o seu contato com a natureza, herdado de sua condição anteriormente animalesca no processo produtivo, exige. Com os primórdios da agricultura, ao invés de modificar apenas elementos naturais de acordo com suas finalidades, cresce a necessidade e a possibilidade do ser humano controlar, mesmo que minimamente, os seus iguais. Por mais simples que seja a divisão do trabalho, ela exige uma ação coordenada dos sujeitos. Um grupo social precisa, ao menos inicialmente, estabelecer uma razoável unidade para se constituir enquanto tal. Isto exige uma ação articulada que permita a concretização dos fins propostos. A consciência tem papel central, já que o sujeito precisa, para sobreviver, compreender como ocorre a relação com os outros homens e agir, dentro dessas condições, de acordo com suas necessidades. ${ }^{\text {ii }}$

Assim, o fenômeno da decadência aponta um tipo particular de ideologia: uma resposta que ao invés de propor a superação do existente, pretende escamotear as contradições postas negando-as por completo através de uma série de recursos regressivos. Estes recursos, tanto de ordem institucional quanto de ordem ideológica, possuem essa característica regressiva por retomarem, muitas vezes com um aspecto de novidade, formas sociais de relação já superadas pela prática humana ao longo da história. Portanto, o fenômeno da decadência ideológica se faz presente a partir do momento contrarrevolucionário burguês, no confronto direto com a classe trabalhadora.

No entanto, essas características comuns ao fenômeno da decadência estiveram presentes, à sua maneira, desde os primórdios da formação da burguesia brasileira. Esta se constitui, em certa medida, a partir das classes dominantes existentes no período colonial brasileiro, e que por sua vez não tiveram a 
necessidade de se confrontar diretamente com nenhuma forma de poder superior que lhes se apresentasse como um entrave ao seu modo de vida. Neste caso, seria possível falar que essa burguesia se insere no fenômeno geral da decadência burguesa? Em caso afirmativo, de que maneira isso ocorreria?

\section{Considerações finais}

Neste momento do artigo, é possível apenas apontar para certas tendências apresentadas ao decorrer da explanação com a intenção de responder, mesmo que deficitariamente, às perguntas postas a pouco.

Se o fenômeno da decadência ideológica remete a um momento de inflexão da burguesia, ou seja, representa uma quebra numa determinada linha de continuidade, a princípio se poderia questionar sua aplicação no caso brasileiro. Afinal, a burguesia nacional se cristaliza em sua condição de classe dentro do capitalismo muito tempo depois de suas expressões análogas europeias, e quando a faz, já apresenta traços de reacionarismo. Ela não parece realizar um processo de decadência, no sentido de anteriormente apresentar soluções para os conflitos de classe e para a manutenção dos elementos básicos da formação social encerrada no território brasileiro. Ao contrário, ela mantém, herdando das elites dominantes anteriores elementos que compõem, essencialmente, um modus operandi político semelhante.

Mas é preciso ressaltar também que, num segundo momento, a categoria de decadência ideológica poderia se apresentar interessante para a apreensão das características da luta de classes no Brasil, especialmente na postura da burguesia. Afinal, se existe um período de inflexão, ele acontece ainda dentro de uma determinada linha de continuidade: a expansão da burguesia enquanto classe dominante no capitalismo a nível mundial. Deste modo, observar o desenvolvimento da burguesia nacional enquanto parte do processo de desenvolvimento da classe dominante mundial pode possibilitar uma maior compreensão da complexidade da expansão da lógica do capital. As respostas de caráter reacionário da burguesia brasileira, ao invés de serem observadas como simplesmente inerentes a sua formação, poderiam ser inseridas num quadro maior de desdobramentos ideológicos, que apontam para 
certa rivalidade entre as burguesias centrais e periféricas do mundo. As respostas dadas por estas últimas poderiam expressar uma condição que combinasse a subserviência com relação às potências rivais e a necessidade de manutenção do poder interno, costurando uma trama econômica que pudesse fluir sem grandes empecilhos para todos no movimento inconstante do mercado mundial.

Então, a categoria de decadência ideológica apresenta fatores que a fazem ser um instrumento analítico interessante para compreender o processo de formação da burguesia nacional brasileira, pois que, partindo das características de suas respostas diante dos conflitos de classe, exige do pesquisador a reconstrução abstrata de processo histórico de sua formação num nível totalizante. Ou seja, os aspectos ideológicos servem de ponto de partida da análise, que deve se aprofundar gradativamente ao nível da economia e das imbricadas relações que se articulam para a conformação do atual estrutura vigente. Aproximar-se-ia, assim, da realidade de uma maneira mais apurada, evitando-se formulações extremadas sobre a ideologia nacional, muitas vezes fechada na questão territorial, outras vezes ignorando-a quase que por completo.

\section{NOTAS}

\footnotetext{
${ }^{i}$ No entanto, é importante ressaltar que apesar dessa caracterização básica, o capitalismo pode se apresentar de formas muito variadas. Como toda formação social se baseia na maneira como se produzem e reproduzem suas condições de vida, cada uma com sua própria dinâmica, torna-se necessário alterar sua configuração através da sobreposição de elementos novos surgidos no âmago da antiga ordem. Cf. HARVEY, D. A justiça social e a cidade [tradução de Armando Correa da Silva]. São Paulo: Hucitec, 1980, passim.

ii O crescimento irresistível do mercado mundial promoveu o lançamento de uma quantidade considerável de mercadorias por todas as partes, incluindo as formas de consumo e gerência da produção. Em outras palavras, a lógica do capital se expande por todo o mundo, e sua tendência monopolística derivada da concorrência alcança a mesma amplitude. Se a junção de capital industrial e capital bancário, que corrobora a formação do capital financeiro e sua prática de exploração baseada na extorsão de juros, acirram os conflitos de classe dentro de um determinado território, com a transposição dessa prática a nível mundial, surgem novas formas de dependência econômica entre os países. Cf. LENIN, V. O imperialismo: fase superior do capitalismo [tradução de Olinto Beckerman]. 2ª ed. São Paulo: Global, 1982, passim.

iii 5 A política do "café com leite" foi um episódio da República Velha que representava o pacto oligárquico entre os grandes cafeicultores paulistas e os pecuaristas mineiros, demonstrando a pouca diversidade da economia e a falta de organização política das camadas urbanas, pouco desenvolvidas. Cf. COSTA, F. L. "Brasil: 200 anos de Estado; 200 anos de administração pública; 200 anos de reformas" In: Revista Administração Pública. Rio de Janeiro, 42(5), SET/OUT, 2008, pp. 829-874.
} 


\begin{abstract}
v O período da República Velha, ao qual fizemos referência algumas notas atrás, é pródigo em exemplos dessa disputa regional, e de como a alternativa escolhida para a solução dos problemas foi a acomodação das elites regionais em relações de subserviência econômica. A política dos governadores é exemplar nesse sentido. Ainda é preciso destacar como essa resposta de subserviência enfatiza, na esfera política, um tipo de relação marcada pela violência direta, principalmente militar. O coronelismo, fenômeno tal, corrobora essa afirmação. Cf. LEAL, V. N. Coronelismo, enxada e voto: o munícipio e o regime representativo no Brasil. $5^{\text {a }}$ ed. São Paulo: Alfa-Ốmega, 1986, passim.
\end{abstract}

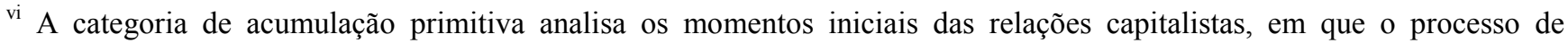
concentração de capitais é associado a um processo violento de expropriação das forças produtivas, através da subjugação de diversos grupos sociais pelas mais variadas expressões das classes dominantes ao redor do mundo. Cf. MARX, K. $O$ Capital: crítica da Economia Política [tradução de Reginaldo Sant'Anna]. 12 ed. Livro 1, vol. I \& II. Rio de Janeiro: Bertrand Brasil, 1988, pp. 828-882.

vii O termo é cunhado por Gyorgy Lukács, em um ensaio intitulado "Marx e o problema da decadência ideológica", in Marxismo e teoria da literatura [tradução de Carlos Nelson Coutinho]. $2^{\mathrm{a}}$ ed. São Paulo: Expressão Popular, 2010, pp. 51103.

viii LUKÁCS, Gyorgy. "Marx e o problema da decadência ideológica", in Marxismo e teoria da literatura [tradução de Carlos Nelson Coutinho]. 2a ed. São Paulo: Expressão Popular, 2010, p. 53.

${ }^{\text {ix }}$ Ibidem, p. 56.

${ }^{\mathrm{x}}$ Com o desenvolvimento das formações sociais ao redor do mundo, surgem conflitos marcados pela atividade produtiva e o controle sobre outras pessoas se torna um instrumento importante nessas lutas. Assim, segundo Lukács, essa nova posição teleológica se torna a "base espiritual-estruturante" daquilo que o marxismo chama de ideologia. Cf. LUKÁCS, G. As bases ontológicas do pensamento e da atividade do homem [tradução de Carlos Nelson Coutinho]. In: TEMAS de Ciências Humanas. São Paulo: Ciências Humanas, 1978, p. 9, nº 4.

${ }^{x i}$ A condição humana foi pautada, desde sempre, por essa perspectiva. A revolução neolítica, que significou o processo de domesticação de plantas e animais iniciado por volta de a mais de 11 mil anos atrás, foi um processo importante nesse sentido. Por permitir a formação de um excedente econômico que demandava uma organização mais eficiente do grupo para sua distribuição e consumo, fez com que os grupos pudessem se tornar autossuficientes, fortificando o caráter social de sua condição. A autossuficiência dos diversos grupos combinada com a grande variedade de recursos naturais distribuídos por todo o planeta, aliada, ainda, com o caráter sempre inovador da ação humana, promoveu o surgimento de um sem-número de culturas, cada uma com suas características, cada uma fornecendo algum tipo diferente de respostas aos mais variados problemas postos. Cf. CHILDE, Gordon. A evolução cultural do homem [tradução de Waltensir Dutra]. $4^{\mathrm{a}}$ ed. Rio de Janeiro: Zahar, 1978, pp. 77-101.

\title{
Referências bibliográficas
}

BANDEIRA, M. O governo João Goulart: as lutas sociais no Brasil: 1961-1964. $6^{\text {a }}$ ed. Rio de Janeiro: Civilização Brasileira, 1983.

CHILDE, G. A evolução cultural do homem [tradução de Waltensir Dutra]. 4a ed. Rio de Janeiro: Zahar, 1978. 
COSTA, F. L. "Brasil: 200 anos de Estado; 200 anos de administração pública; 200 anos de reformas" In: Revista Administração Pública. Rio de Janeiro, 42(5), SET/OUT, 2008, pp. 829-874.

FAUSTO, B. A revolução de 1930: historiografia e história. $3^{\mathrm{a}}$ ed. São Paulo: Brasiliense, 1975.

FERNANDES, F. A revolução burguesa no Brasil: ensaio de interpretação sociológica. Rio de Janeiro: Zahar, 1975.

HARVEY, D. A justiça social e a cidade [tradução de Armando Correa da Silva]. São Paulo: Hucitec, 1980.

HOBSBAWM, E. A era das revoluções: 1789-1848 [tradução de Maria Tereza Lopes Teixeira \& Marcos Penchel] - 19a ed. São Paulo: Paz e Terra, 2005.

LEAL, V. N. Coronelismo, enxada e voto: o munícipio e o regime representativo no Brasil. 5 a ed. São Paulo: Alfa-Ômega, 1986.

LENIN, V. O imperialismo: fase superior do capitalismo [tradução de Olinto Beckerman]. $2^{\mathrm{a}}$ ed. Global: São Paulo, 1982.

LUKÁCS, G. "Marx e o problema da decadência ideológica", in Marxismo e teoria da literatura [tradução de Carlos Nelson Coutinho]. $2^{\mathrm{a}}$ ed. São Paulo: Expressão Popular, 2010, p.

- As bases ontológicas do pensamento e da atividade do homem [tradução de Carlos Nelson Coutinho]. In: TEMAS de Ciências Humanas, $n^{\circ}$ 4. São Paulo: Ciências Humanas, 1978, p.

MARX, K. O Capital: crítica da Economia Política [tradução de Reginaldo Sant'Anna] 12ª ed. Livro 1, vol. I \& II. Rio de Janeiro: Bertrand Brasil, 1988.

PRADO JR., C. Formação do Brasil contemporâneo: Colônia. São Paulo: Brasiliense; Publifolha, 2000.

SANTA ROSA, V. O sentido do Tenentismo. $3^{\text {a }}$ ed. São Paulo: Alfa-Ômega, 1976. 